\title{
Trivalent Mn and Fe Complexes for the Degradation of Remazol Dyes
}

\author{
Siguara Bastos de Lemos e Silva, Anderson Arndt, Breno Pannia Espósito \\ Instituto de Química, Universidade de São Paulo, \\ Av Lineu Prestes, São Paulo, Brazil \\ E-mail:breno@iq.usp.br \\ Received December 31, 2009; revised January 20, 2010; accepted January 20, 2010
}

\begin{abstract}
Water contamination by Remazol ${ }^{\circledR}$ dyes can be remediated with the use of bleaching metal complexes. In this study, a series of $\mathrm{Mn}$ (III) complexes and ferric nitrilotriacetate were found to be useful in the degradation of Remazol Blue, Remazol Turquoise and Remazol Brilliant Blue. The effect of peroxide, $\mathrm{pH}$, time and irradiation on the bleaching of the dyes was studied. Mn(III)-salen complexes were effective in the degradation of the diazo Remazol Blue dye in the presence of a 2-fold excess of hydrogen peroxide. This dye was also effectively bleached by a combination of hydrogen peroxide, ferric nitrilotriacetate and light irradiation. This is the first time well-defined, low molecular weight trivalent metal complexes are applied to the degradation of Remazol ${ }^{\circledR}$ dyes.
\end{abstract}

Keywords: Manganese, Iron, Remazol Dye

\section{Introduction}

Water contamination by remnants of organic dyes in the effluents of textile plants is of great environmental concern due to the potentially toxic effects of relatively small amounts of these compounds [1].

Vinyl sulfone (Remazol $\left.{ }^{\circledR}\right)$ reactive dyes are among the pollutants whose presence in aqueous systems is undesirable. Thus, a number of physical and biological detoxification methods have been devised [2]. The use of oxidant metal species for the treatment of organic contamination is an example of chemically-assisted detoxification methods. A common strategy is to take advantage of the in situ generation of hydroxyl radicals through the reaction between Fe(II) species and peroxide (Fenton reaction, Equation 1) or, provided that a chromophoric metal complex is available, through a combination of UV irradiation, $\mathrm{Fe}(\mathrm{III})$ species and peroxide (Photo-Fenton reaction, Equation 2) [3].

$$
\begin{gathered}
\mathrm{Fe}^{2+}+\mathrm{H}_{2} \mathrm{O}_{2} \rightarrow \mathrm{Fe}^{3+}+{ }^{\bullet} \mathrm{OH}+\mathrm{OH}^{-} \\
\mathrm{Fe}^{3+}+\mathrm{H}_{2} \mathrm{O} \rightarrow \mathrm{Fe}(\mathrm{OH})^{2+}+\mathrm{H}^{+} \\
\mathrm{Fe}(\mathrm{OH})^{2+}+h v \rightarrow \mathrm{Fe}^{2+}+{ }^{\bullet} \mathrm{OH}
\end{gathered}
$$

Other high valence, oxidant metal complexes which may or may not generate reactive oxygen species in the environment may also be of use. Manganese $(\mathrm{Mn})$ is a constitutive element of a number of redox-active enzymes involved in the detoxification of highly reactive oxygen species and in electron-transfer processes [4] in organisms. This catalytic role underlines the use of fungal and/or bacterial Mn-enzymes in the bioremediation of organic wastes, including dyes, such as peroxidases [5, 6] or laccases [7,8]. Also, simple Mn salts [9,10], complexes [11] or oxides [12] have been successfully applied to water remediation after dye contamination.

$\mathrm{Mn}$ (III) complexes have been proposed as mimetics of antioxidant enzymes such as catalase [13] and superoxide dismutase [14]. However, it is also well established that $\mathrm{Mn}(\mathrm{III})$ species are strong oxidants per se, leading to their use in organic catalysis [15]. Mn(III)-citrate is believed to be the main Mn species to assess the brain in humans [16], leading to a cascade of redox-active-based neurotoxic events. In combination with certain proportions of hydrogen peroxide, Mn(III) enzyme mimetics may oxidize redox-sensitive fluorescent probes [17]. Therefore, high-valence Mn complexes have also found interesting applications in advanced oxidation of dyes in wastewater [18-20].

Herein, we report for the first time the use of one $\mathrm{Fe}(\mathrm{III})$ and a number of potential $\mathrm{Mn}$ (III) oxidant complexes in the degradation of Remazol ${ }^{\circledR}$ dyes, which may contribute to approaches such as whole enzyme and/or 
organisms in pollutant degradation. The effects of reaction time, $\mathrm{pH}, \mathrm{H}_{2} \mathrm{O}_{2}$ and irradiation were studied photometrically in 96-well microplates.

\section{Materials and Methods}

The metal complexes $\mathrm{Mn}$ (III)-desferrioxamine B (Mndfb [14]), Mn(III)-pyrophosphate (Mn-pyr [21]), Mn (III)-salen chloride (EUK 8) and acetate (EUK 108) [13] were prepared and characterized by previously published methods. Iron(III) nitrilotriacetate (Fe-nta) was prepared by the direct reaction of $\mathrm{Fe}\left(\mathrm{NH}_{4}\right)\left(\mathrm{SO}_{4}\right)_{2} \cdot 6 \mathrm{H}_{2} \mathrm{O}$ with a 3 fold mol excess of sodium nitrilotriacetate under air. $\mathrm{MnCl}_{2}$ was used as a divalent $\mathrm{Mn}$ control. The Remazol® dyes were from Dystar (Suzano, Brazil) and used as aqueous solutions in deionized water. Absorbance measurements were performed in a FluoStar Optima photometer (BMG LabTech) at $595 \mathrm{~nm}$. Absorbance values were corrected for the absorption of the metal complexes and normalized in relation to the complex-untreated controls. The time of reaction between the dyes and the metal complexes was $1 \mathrm{~h}$ (dark; room temperature) unless otherwise noted. When required, irradiation was performed with an $8 \mathrm{~W}$ (12") Aqua-Glo fluorescent tube. Assays were performed in duplicate.

\section{Results and Discussion}

In order to determine the influence of peroxide to achieve maximum bleaching, experiments were undertaken at $[$ dye] $=40 \mu \mathrm{M}$ (Figure 1). In the absence of $\mathrm{H}_{2} \mathrm{O}_{2}$ (Figure 1(a)), the dyes underwent considerable bleaching induced by all the metal species (specially phthalocyanine RT and anthraquinone RBB), an effect which may be related either to the presence of $\mathrm{O}_{2}$ in the solvents used, which can generate reactive species in the presence of metal species [22] or to the direct attack of the metal species on the dyes. This effect stabilizes at dye:complex mol ratios of $c a$. 1. The diazo dye RB is more clearly affected by higher complex concentrations (see in continuation).

Hydrogen peroxide alone did not cause any dye bleaching under the test conditions for up to a 5-fold molar excess in relation to the dye (data not shown). No improved bleaching for RT was found which could be attributed to the effect of peroxide (Figure 1(b)), indicating that none of the complexes studied would require peroxide to bleach this dye. However, the salen complexes EUK 8 and EUK 108 displayed considerable bleaching power towards the diazo dye $\mathrm{RB}$ and, to a lesser extent, to $\mathrm{RBB}$ in $\mathrm{a} \sim 2: 1 \mathrm{H}_{2} \mathrm{O}_{2}$ :metal complex mol ratio, which is in agreement with previous studies on oxidizable fluorescent probes [17]. In both complexes, $\mathrm{Mn}$ (III) lies in a planar environment with a free axial coordination position available for the reaction with per-
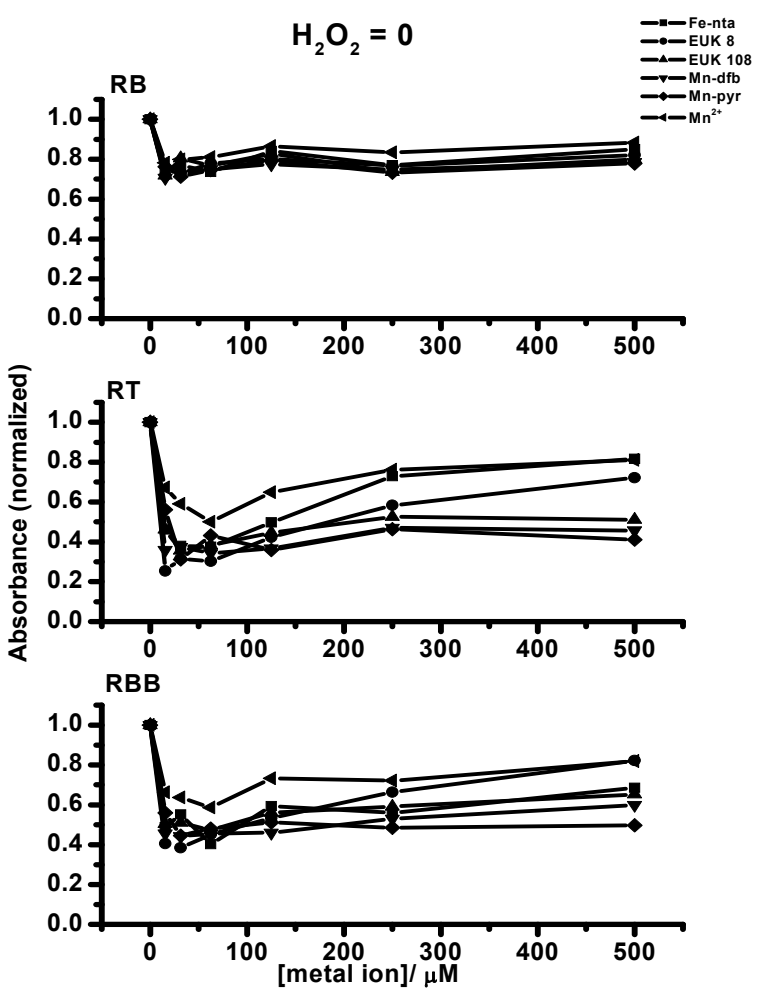

(a)
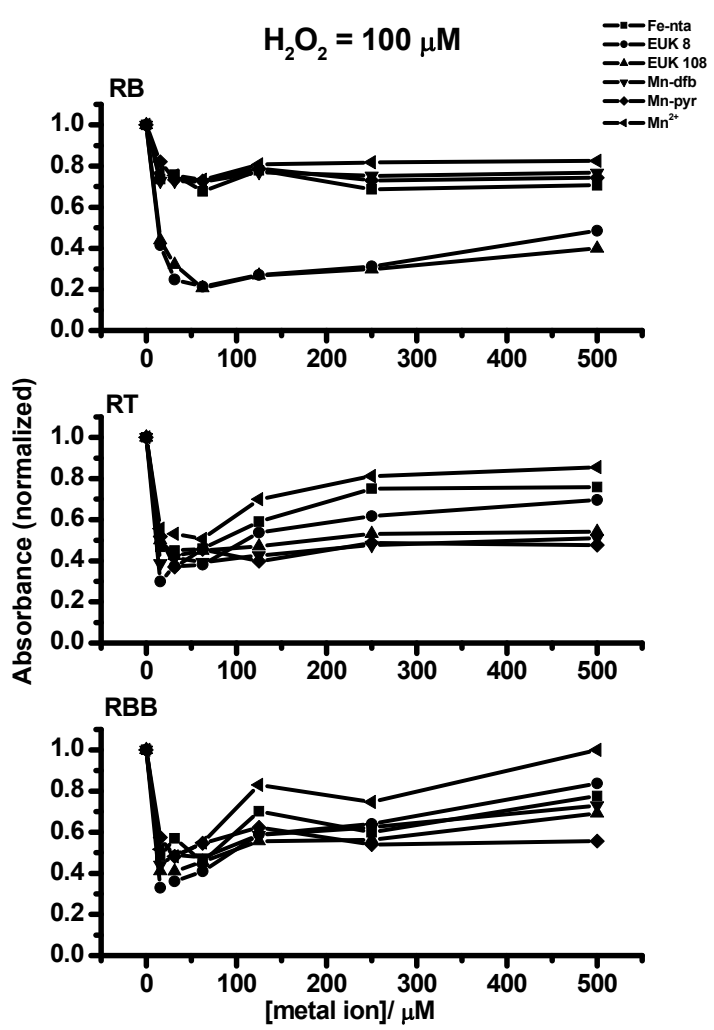

(b)

Figure 1. Effect of $\mathrm{H}_{2} \mathrm{O}_{2}$ on the bleaching induced by the metal complexes $([$ dye $]=40 \mu \mathrm{M})$. 
oxide (for a detailed mechanism, see [13]). Under oxidation to $\mathrm{Mn}(\mathrm{V})$, the metal center might reasonably attack the electron-rich azo moiety, as observed in other instances of electrophilic attack [23].

In general terms, no marked trend in the effect of $\mathrm{pH}$ on the bleaching activity of the complexes was observed (Figure 2), except for $\mathrm{RB} / \mathrm{H}_{2} \mathrm{O}_{2}$ at neutral $\mathrm{pH}$ values for the salen complexes EUK 8 and EUK 108, where maximum decolorization was attained. This is to be expected since the ability of salen ligands to form Mn complexes is $\mathrm{pH}$-dependent, and is greatest at close to neutral $\mathrm{pH}$ [24]. A high proton concentration may result in reprotonation of the salen ligand, whereas alkaline conditions promote metal hydrolysis.

The effect of reaction time and dye:complex ratios were investigated for EUK 8, due to its good decolorization properties (Figure 3). Hydrogen peroxide was not added since it would decompose during the initial time periods investigated. Maximum bleaching was observed at $c a$. 1-2 h of incubation for RB, but was attained considerably later for the other dyes, especially at high dye concentration. Long-term expositions resulted in more efficient bleaching when dye:complex ratios are low.

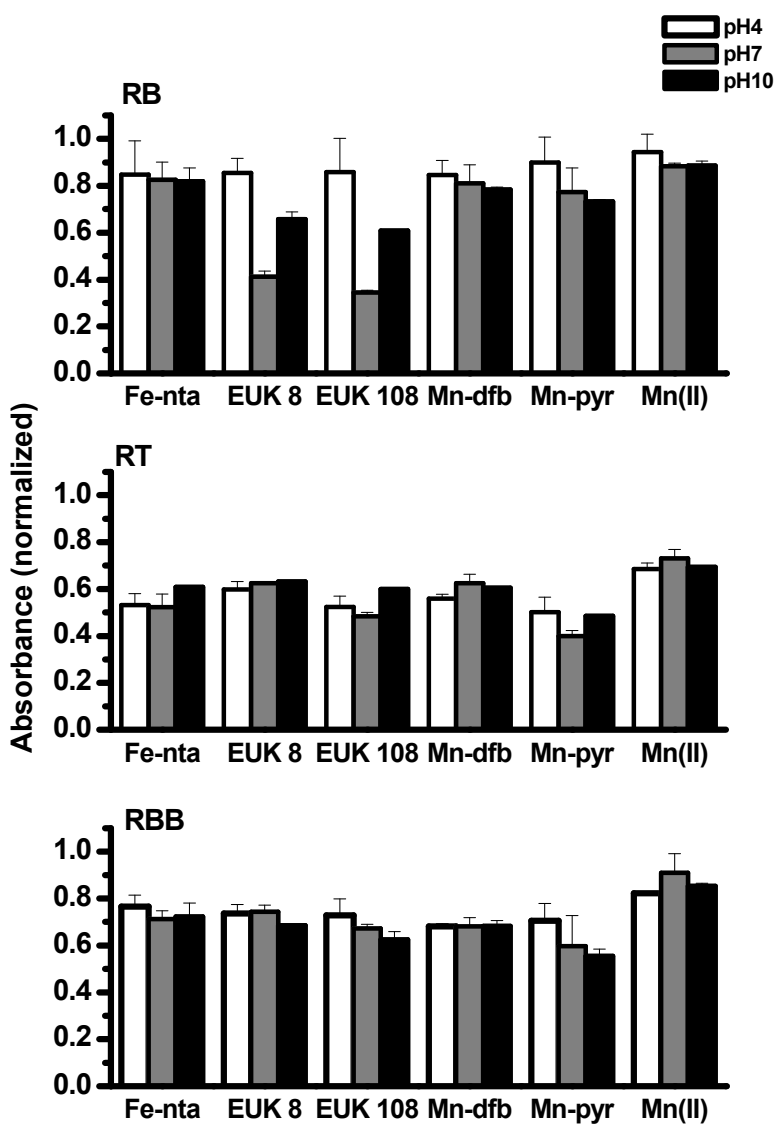

Figure 2. Effect of $\mathrm{pH}$ on the bleaching induced by the metal complexes ([metal complex] $=50 \mu \mathrm{M}$, [dye $]=40 \mu \mathrm{M}$; for $\mathrm{RB}$ : $\left.\left[\mathrm{H}_{2} \mathrm{O}_{2}\right]=100 \mu \mathrm{M}\right)$.

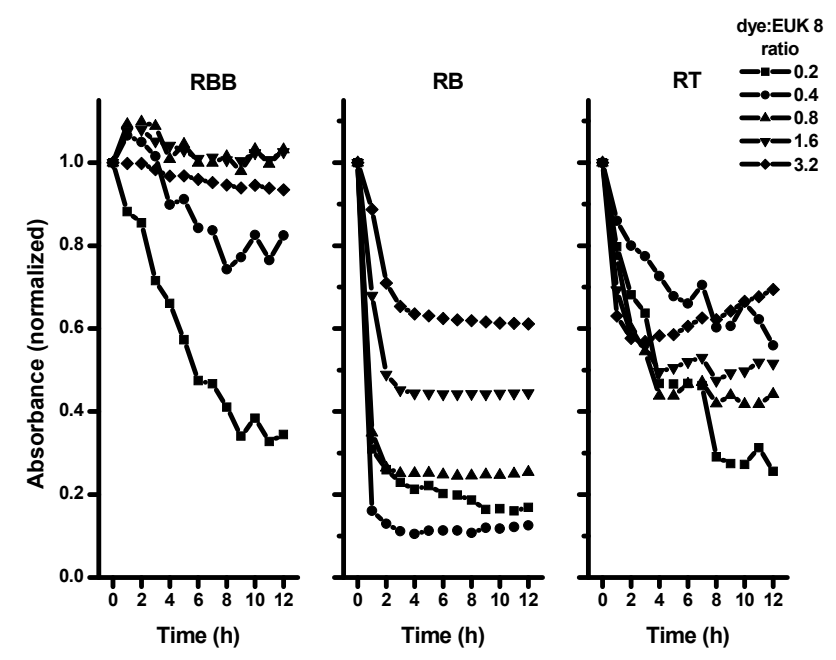

Figure 3. Effect of reaction time and dye concentration on the performance of $50 \mu \mathrm{M}$ EUK 8.

Ferric nitrilotriacetate (Fe-nta) is an inexpensive, stable, easily obtained $\mathrm{Fe}$ (III) chromophoric complex that can be useful in photo-Fenton oxidative processes. There were no previous reports on the use of this complex for the remediation of dye contaminated water. Fe-nta is reduced by light to the ferrous derivative which, in aqueous aerated solution, may form reactive oxygen species [22] via a photo-Fenton process, as shown in Equation 2. In the presence of hydrogen peroxide, the divalent Fe species may undergo further generation of free radicals via the Fenton mechanism (Equation 1), indicating that a synergism exists between light and $\mathrm{H}_{2} \mathrm{O}_{2}$ in this situation. We observed this effect when comparing the effect of time and irradiation on the bleaching of RB induced by Fe-nta (Figure 4). In the absence of light, reactive species, if formed, do not seem to be able to degrade this dye. However, irradiation increased significantly RB bleaching in the presence of $\mathrm{H}_{2} \mathrm{O}_{2}$ :Fe-nta in a ca. 1:1 mol ratio. To the best of our knowledge, this is the first report of the use of ferric nitrilotriacetate for degradation of a dye. We did not find evidence of irradiation-increased bleaching promoted by the $\mathrm{Mn}$ (III) complexes, indicating that the active $\mathrm{Mn}$ (III) complexes should act by either the formation of reactive oxygen species from saturation $\mathrm{O}_{2}$ in water or, when peroxide is available, via formation of highly reactive $\mathrm{Mn}(\mathrm{V})$ species.

\section{Conclusions}

Trivalent metal complexes are interesting candidates for the degradation of Remazol ${ }^{\circledR}$ dyes in neutral aqueous medium. Mn(III)-salen complexes are most effective in the degradation of the diazo RB when in the presence of a ca. 2-fold molar excess of hydrogen peroxide. This dye is also prone to degradation via a photo-Fenton process under Fe-nta. 

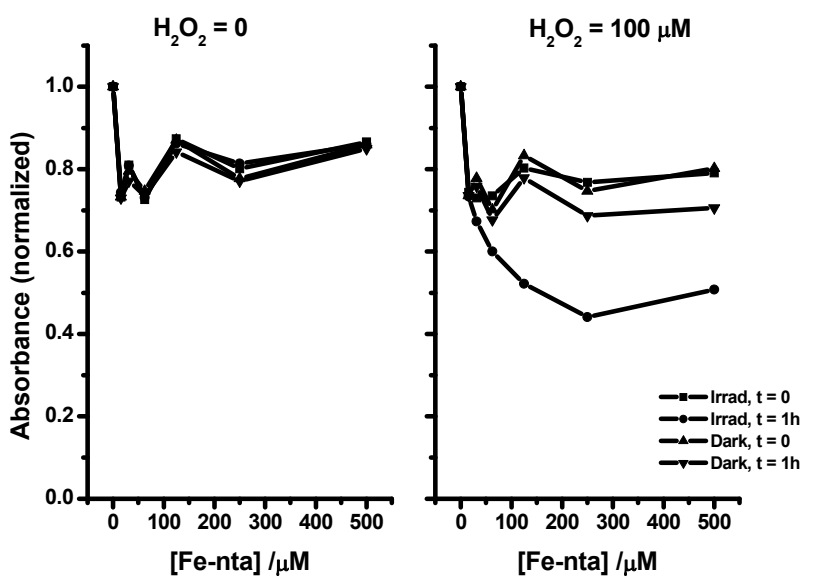

Figure 4. Effect of time and irradiation on the bleaching of $40 \mu$ M RB promoted by Fe-nta.

\section{Acknowledgments}

Authors are thankful for funding from the Brazilian agencies CNPq and FAPESP. Dye samples were kindly donated by Prof. Renato Freire.

\section{References}

[1] C. I. Pearce, J. R. Lloyd, and J. T. Guthrie, "The removal of colour from textile wastewater using whole bacterial cells: A review," Dyes and Pigments, Vol. 58, No. 3, pp. 179-196, 2003.

[2] Z. Aksu, "Application of biosorption for the removal of organic pollutants: A review," Process Biochemistry, Vol. 40, No. 3-4, pp. 997-1026, 2005.

[3] P. Bautista, A. F. Mohedano, J. A. Casas, J. A. Zazo, and J. J. Rodriguez, "An overview of the application of Fenton oxidation to industrial wastewaters treatment," Journal of Chemical Technology and Biotechnology, Vol. 83, No. 10, pp. 1323-1338, 2008.

[4] B. Halliwell and J. Gutteridge, "Free radicals in biology and medicine," Oxford University Press, 2007.

[5] M. Shakeri and M. Shoda, "Change in turnover capacity of crude recombinant dye-decolorizing peroxidase ( $\mathrm{rDyP})$ in batch and fed-batch decolorization of Remazol Brilliant Blue R," Applied Microbiology and Biotechnology, Vol. 76, No. 4, pp. 919-926, 2007.

[6] M. Shakeri, Y. Sugano, and M. Shoda, "Stable repeated-batch production of recombinant dye-decolorizing peroxidase (rDyP) from Aspergillus oryzae," Journal of Bioscience and Bioengineering, Vol. 105, No. 6, pp. 683-686, 2008.

[7] P. P. Champagne and J. A. Ramsay, "Contribution of manganese peroxidase and laccase to dye decoloration by Trametes versicolor," Applied Microbiology and Biotechnology, Vol. 69, No. 3, pp. 276-285, 2005.

[8] K. Svobodova, A. Majcherczyk, C. Novotny, and U. Kues, "Implication of mycelium-associated laccase from
Irpex lacteus in the decolorization of synthetic dyes," Bioresource Technology, Vol. 99, No. 3, pp. 463-471, 2008.

[9] K. Pachhade, S. Sandhya, and K. Swaminathan, "Ozonation of reactive dye, procion red MX-5B catalyzed by metal ions," Journal of Hazardous Materials, Vol. 167, No. 1-3, pp. 313-318, 2009.

[10] E. Ember, S. Rothbart, R. Puchta R, and R. van Eldik, "Metal ion-catalyzed oxidative degradation of orange II by $\mathrm{H}_{2} \mathrm{O}_{2}$ high catalytic activity of simple manganese salts," New Journal of Chemistry, Vol. 33, No. 1, pp. 34 49, 2009.

[11] G. B. Shul'pin, Y. N. Kozlov, S. N. Kholuiskaya, and M. I. Plieva, "Oxidations by the system 'hydrogen peroxide- $\left[\mathrm{Mn}_{2} \mathrm{~L}_{2} \mathrm{O}_{3}\right]^{(2+)} \quad(\mathrm{L}=1,4,7$-trimethyl-1,4,7-triazacyclononane)-oxalic acid' Part 11. Degradation of dye Rhodamine 6G and oxygenation of cyclohexene," Journal of Molecular Catalysis A-Chemical, Vol. 299, No. 1-2, pp. 77-87, 2009.

[12] A. N. Chowdhury, M. S. Azam, M. Aktaruzzaman, and A. Rahim, "Oxidative and antibacterial activity of $\mathrm{Mn}_{3} \mathrm{O}_{4}$," Journal of Hazardous Materials, Vol. 172, No. 2-3, pp. 1229-1235, 2009.

[13] S. R. Doctrow, K. Huffman, C. B. Marcus, G. Tocco, E. Malfroy, C. A. Adinolfi, H. Kruk, K. Baker, N. Lazarowych, J. Mascarenhas, and B. Malfroyt, "Salen-manganese complexes as catalytic scavengers of hydrogen peroxide and cytoprotective agents: Structure-activity relationship studies," Journal of Medicinal Chemistry, Vol. 45, No. 20, pp. 4549-4558, 2002.

[14] K. M. Faulkner, R. D. Stevens, and I. Fridovich, "Characterization of $\mathrm{Mn}(\mathrm{III})$ complexes of linear and cyclic desferrioxamines as mimics of superoxide-dismutase activity," Archives of Biochemistry and Biophysics, Vol. 310, No. 2, pp. 341-346, 1994.

[15] T. Katsuki, "Catalytic asymmetric oxidations using optically-active (salen)manganese(III) complexes as catalysts," Coordination Chemistry Reviews, Vol. 140, pp. 189-214, 1995.

[16] J. S. Crossgrove, D. D. Allen, B. L. Bukaveckas, S. S. Rhineheimer, and R. A. Yokel, "Manganese distribution across the blood-brain barrier: I. Evidence for carrier-mediated influx of manganese citrate as well as manganese and manganese transferring," Neurotoxicology, Vol. 24, No. 1, pp. 3-13, 2003.

[17] S. do Amaral and B. P. Esposito, "Fluorimetric study of the pro-oxidant activity of EUK8 in the presence of hydrogen peroxide," Biometals, Vol. 21, No. 4, pp. 425-432, 2008.

[18] J. J. Dannacher, "Catalytic bleach: Most valuable applications for smart oxidation chemistry," Journal of Molecular Catalysis A-Chemical, Vol. 251, No. 1-2, pp. 159-176, 2006.

[19] T. Wieprecht, M. Hazenkamp, H. Rohwer, G. Schlingloff, and J. T. Xia, "Design and application of transition metal catalysts for laundry bleach," Comptes Rendus Chimie, Vol. 10, No. 4-5, pp. 326-340, 2007.

[20] P. Zucca, C. Vinci, F. Sollai, A. Rescigno, and E. Sanjust, "Degradation of alizarin red S under mild experimental 
conditions by immobilized 5,10,15,20-tetrakis(4-sulfonatophenyl)porphine- $\mathrm{Mn}$ (III) as a biomimetic peroxidase-like catalyst," Journal of Molecular Catalysis AChemical, Vol. 288, No. 1-2, pp. 97-102, 2008.

[21] J. K. Klewicki and J. J. Morgan, "Kinetic behavior of $\mathrm{Mn}$ (III) complexes of pyrophosphate, EDTA, and citrate," Environmental Science \& Technology, Vol. 32, No. 19, pp. 2916-2922, 1998.

[22] K. Tsuchiya, K. Akai, A. Tokumura, S. Abe, T. Tamaki, Y. Takiguchi, and K. Fukuzawa, "Oxygen radicals photoinduced by ferric nitrilotriacetate complex," Biochimica et Biophysica Acta-General Subjects, Vol. 1725, No. 1, pp. 111-119, 2005.

[23] A. Chellamani, P. Kulanthaipandi, and S. Rajagopal, "Oxidation of aryl methyl sulfoxides by oxo (salen) manganese(V) complexes and the reactivity-selectivity principle," Journal of Organic Chemistry, Vol. 64, No. 7, pp. 2232-2239, 1999.

[24] G. Tantaru, V. Dorneanu, and M. Stan "Schiff bis bases: Analytical reagents: II. Spectrophotometric determination of manganese from pharmaceutical forms," Journal of Pharmaceutical and Biomedical Analysis, Vol. 27, No. 5, pp. 827-832, 2002. 